\title{
Projections of Temperature, Precipitation and Snow Cover Area over Iran During the $21^{\text {st }}$ Century
}

\author{
Mohammad Zarenistanak \\ Research Institute of Shakhes Pajouh Isfahan, Iran \\ Email: zareclima@gmail.com
}

\begin{abstract}
In this paper, results of the projections of temperature, precipitation and snow cover area for the $21^{\text {st }}$ century over Iran is presented. The future projections were carried out at Centre National de Recherché Meteorologiques (CNRM), European Center Hamburg Model (ECHAM), and United Kingdom Meteorological Office (UKMOC) for contribution to the Fourth Assessment Report of the Intergovernmental Panel on Climate Change (IPCC AR4), underB1 and $\mathrm{A} 1 \mathrm{~B}$ emission scenarios. The analysis of temperature projections revealed that temperature may increase between 1.27 to $5.38^{0} \mathrm{C}$ by the end of the twenty-first century. Summer temperature may increase with higher rates than other season. Precipitation projection shows that precipitation will decrease annually, through winter, spring and summer in Iran by 2100 . Total annual precipitation may decrease by $-9.92 \%$ under B1 scenario and $-8.18 \%$ under A1B scenario. Autumn precipitation may increase at the end of this century under B1 and A1B emission scenarios. Snow cover projection was conducted relative to snow cover-observed period which included the months of December, January, February, March and April. The result of snow cover projection showed that snow cover area might decrease as indicated by CNRM, ECHAM, and UKMOC models under $\mathrm{B} 1$ and $\mathrm{A} 1 \mathrm{~B}$ emission scenarios by the end of the $21^{\text {st }}$ century. On average, snow cover area may decrease by -224040 and $-242883 \mathrm{~km}^{2}$ under B1 and A1B scenarios compared to 1981-2000. Spatial variation, annual temperature and precipitation between 2081-2100 and 1981-2000 over Iran show that temperature may increase more in central and west parts of Iran and various patterns of precipitation will not be uniform across the country. Spatial variation of snow cover area during snow cover-observed period shows that the northern half of the country will witness snow coverage in the late current century while the southern half will face no snow cover.
\end{abstract}

Keywords: Projection; scenarios; temperature; precipitation; snow cover; Iran

\section{Introduction}

The Fourth Assessment report of the Intergovernmental Panel on Climate Change indicated that the future temperature might increase due to the increase in Greenhouse Gas (GHG) concentrations (IPCC, 2007). In the past decades, Iran's average temperature has been found to increase. In the recent 50 years, the annual average temperature in Iran has seen an increase of $0.224^{0} \mathrm{C} /$ decade (Tabari et al., 2012). Climate model projections showed that global mean temperatures will increase in this century. The $21^{\text {st }}$ century temperature is expected to increase between 1.5 and $5.7^{\circ} \mathrm{C}$ by 2100 in Asia depending on scenarios (IPCC, 2007).

Increasing temperatures causes snow cover retreat and changes in the global patterns of precipitation. Changes in precipitation and snow cover area will affect water resources, 
river runoff, hydrologic conditions, duration of the growing season and energy (De'ry et al., 2005; Wulder et al., 2007). Any significant changes in temperature, precipitation and snow cover area are important for water resource management, policy makers, industry and agriculture.

Projections of temperature, precipitation and snow cover have been investigated by many researchers throughout the world (Park et al., 2014; Dash et al., 2013; Levine et al., 2013; Osca et al., 2013; Dash et al., 2012; Yang et al., 2012; Terray et al., 2011; Bartholy and Pongracz, 2010; Jylhä et al., 2008).

Faggian and Giorgi (2009) used 20 Atmospheric-Ocean General Circulation Models (AOGCMs) under A2, A1B and B1 scenarios for projection of temperature and precipitation of the end of the $21^{\text {st }}$ century over the Alpine Region. The results showed that temperature would increase between $2-4^{0} \mathrm{C}$ and the models projected decrease in annual-mean precipitation by 2100 in the study area. Callaghan et al. (2011) applied global climate models for projection of snow cover in Arctic. The results indicated that snow cover duration is projected to decrease by about $10-20 \%$ over most of the Arctic, with the smallest decrease over Siberia $(<10 \%)$ and the largest decrease over Alaska and northern Scandinavia (30-40 $\%$ ) by 2050 . Future projections of precipitation and temperature from three RCMs by Dibike et al. (2012) under A2 emission scenario in the Lake Winnipeg indicated that precipitation and temperature will increase by $5.5-7.7 \%$ and $2.1-2.8^{0} \mathrm{C}$ from $2041-2070$ compared to the 1980s. Ribalaygua et al. (2013) employed statistical downscaling technique to four climate models under A2, A1B and B1 scenarios over the Spanish region of Aragón. The result indicated that maximum temperature will increase about $3.75^{\circ} \mathrm{C}, 3.3^{0} \mathrm{C}$, and $2.1^{0} \mathrm{C}$ for $\mathrm{A} 2$, $\mathrm{A} 1 \mathrm{~B}$, and $\mathrm{B} 1$ scenarios and the minimum temperature will increase about $3.1^{\circ} \mathrm{C}, 2.75^{\circ} \mathrm{C}$, and $1.75^{\circ} \mathrm{C}$, respectively. Nonetheless, all the scenarios suggested a moderate decrease in rainfall at the end of the century (4.5-5.5\%). Terray and Boe (2013) studied France's climate evolution during the $20^{\text {th }}$ and $21^{\text {st }}$ century. The result showed that France average annual mean temperature at the end of the $21^{\text {st }}$ century is projected to be on the order of $4.5 \mathrm{~K}$ warmer than in the early $20^{\text {th }}$ century under the RCP8.5 scenario. Model projections also suggested a substantial summer precipitation decrease $(-0.6 \mathrm{~mm} /$ day $)$, particularly over southern France, and a moderate winter increase, $(0.3 \mathrm{~mm} /$ day $)$, mostly over the northernmost part of France. Another study by Senatore et al. (2011) showed that annual temperature would increase between $3.5^{\circ} \mathrm{C}$ and $3.9^{\circ} \mathrm{C}$, while annual precipitation will decrease between $-9 \%$ and $-21 \%$. Also, snow accumulation will decrease between $-82 \%$ and $92 \%$ over Mediterranean basin in Southern Italy in 2100. Gobiet et al. (2014) applied A1B emission scenario over Alpine region for projection of temperature, precipitation and snow cover. The result indicated that temperature is expected to rise by $0.36^{0} \mathrm{C}$ per decade in the second half of the century. The annual precipitation is expected to change considerably until the end of the $21^{\text {st }}$ century with decrease in precipitation in summer, particularly in the southern regions. Snow cover is expected to drastically decrease below 1500-2000 m, and natural hazards related to glacier and permafrost retreat are expected to become more frequent. Ragab and Prudhomme (2002) studied the UK Hadley Center's global climate model under different scenarios. According to this analysis, rainfall will have a reduction at rate of 20-25\% less than the present mean values in North Africa and some parts of Egypt, Iran, Jordan and Syria during the dry season (April-September), by the 2050s, where temperature is expected to increase about $2-2.75^{\circ} \mathrm{C}$. It has also been shown that the temperature changes would affect the evapotranspiration rates, storm intensity, soil moisture and snowmelt regimes and snowfall. 
Open access e-Journal

Earth Science India, elSSN: $0974-8350$

Vol. 10 (II), April, 2017, pp. 63- 81

http://www.earthscienceindia.info/

Research on projections of climate parameter was carried out by the following Iranian scientists: Roshan and Grab (2012) who utilized the MAGICC/SCENGEN 5.3 compound model revealed that precipitation may increase by $36 \%$ relative to that of 1961-1990 at end of $21^{\text {st }}$ century in Iran. Zarenistanak et al. (2014a) found that temperature may increase between 1.69 and $6.88^{\circ} \mathrm{C}$ by 2100 over southwest Iran according to CNRM, ECHAM, MIROCH, and UKMOC models under B1 and A1B emission scenarios. Dhorde et al. (2014) applied CNRM, ECHAM, MIROCH, and UKMOC models under B1 and A1B scenarios for projections of precipitation over southwest Iran. The result of projections showed that precipitation might decrease according to majority of the models under both scenarios. Zarenistanak et al. (2014 b) used CNRM, ECHAM, MIROCH, and UKMOC models under $\mathrm{B} 1$ and $\mathrm{A} 1 \mathrm{~B}$ scenarios for projections of snow cover area over southwest Iran. Snow cover projection showed that snow cover area might decrease according to all the models under both scenarios at the end of $21^{\text {st }}$ century.

Previous studies were limited in one way or another. On one hand, scientists who studied the whole of the country limited their studies to using only one model or one scenario. On the other hand, Zarenistanak et al. (2014a, b) and Dhorde et al. (2014) used four models under two scenarios but their studies covered only southwestern part of Iran. In the current study, I tried to utilize outputs of three models under two scenarios for projections of temperature, precipitation and snow cover area over the whole Iran.

This research focuses on projection of temperature; precipitation and snow cover over Iran for $21^{\text {st }}$ century. As temperature, precipitation and snow cover are three important climate parameters, examination on this data is useful in understanding the climatic variations impact on water resources, agriculture and policy makers over a given area. Temperature and precipitation projection was studied in term of seasonal scale (winter, spring, summer and autumn) and snow cover projection on snow cover-observed period included the months of December, January, February, March and April in the area. The objective was to project temperature, precipitation and snow cover area over Iran using CNRM, ECHAM, and UKMOC models under B1 and A1B emission scenarios.

\section{Methodology}

\section{Study Area}

Iran covers an area of about $1,648,000 \mathrm{~km}^{2}$, located in the south west of Middle East. The climate of Iran is semi-arid and arid, in most parts of Iran except the north and west parts of the country. The two main mountain ranges in Iran are Zagros and Alborz Mountains. Zagros Mountains extend from the northwest to the southern part of Iran, while the Alborz Mountains extends from the north to the west and east Iran. These mountain ranges have an important role in non-uniform spatial and temporal distribution of precipitation in Iran (Kousari et al., 2011).

The Caspian Sea and Mediterranean Sea are two great sources of humidity and precipitation in Iran. The Alborz ranges stand as main barrier for pushing the humidity from the Caspian Sea to the plateau of Iran, while the Zagros ranges repel the humidity from the Mediterranean Sea by western winds and cyclones in order to cover the central and east plateaus of Iran, turning those regions into semi-arid and arid. The geographical position of Iran is presented in Fig. 1. 


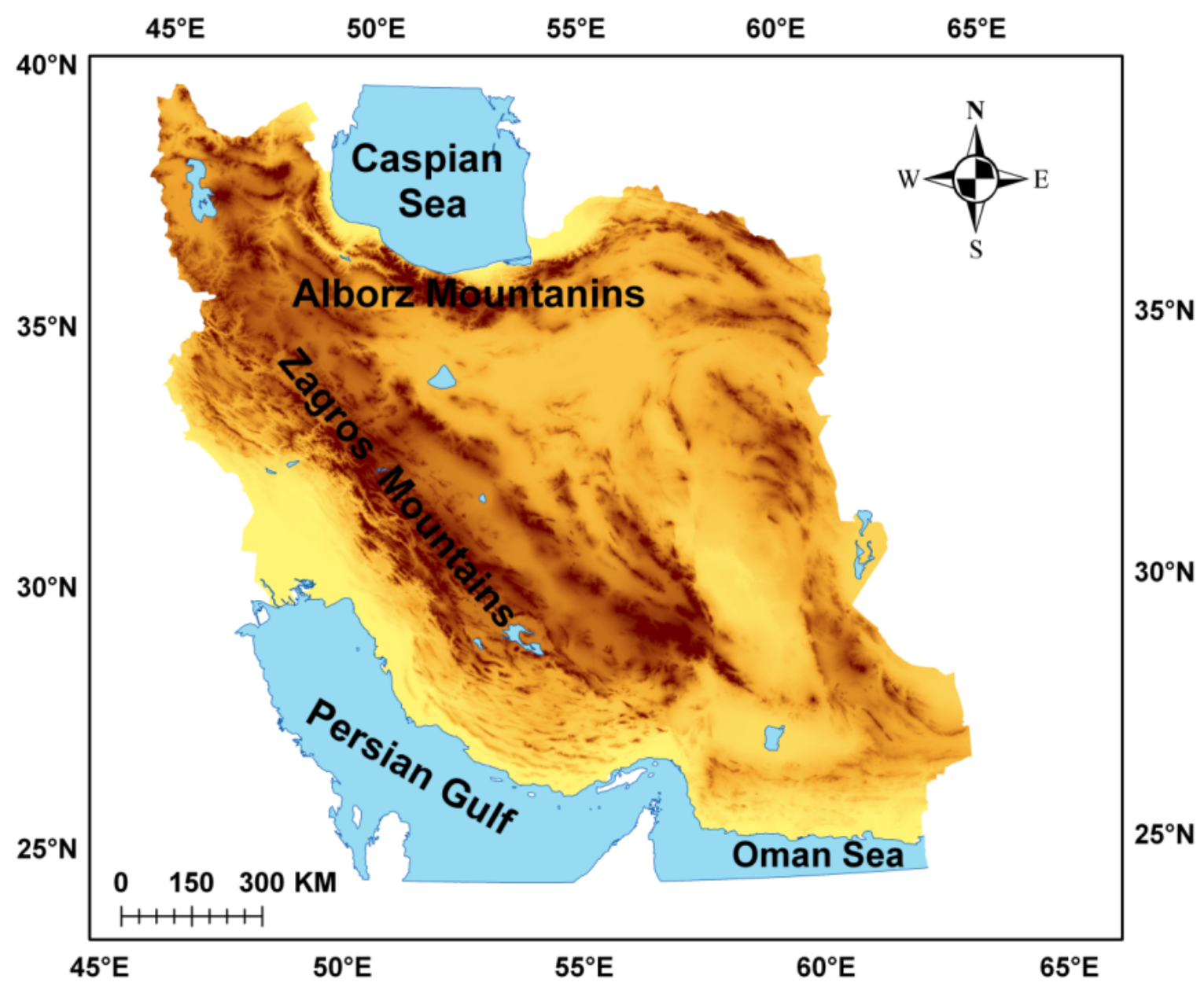

Fig. 1: Topographic map of Iran.

\section{Climate Model Outputs}

This study used three different GCMs associated with the Fourth Assessment Report of the Intergovernmental Panel on Climate Change (Table-1). The IPCC standard output from coupled ocean atmosphere GCMs was collected and archived by the WGCM (Working Group on Coupled Models) Climate simulation panel and the Program for Climate Model Diagnosis and Intercomparison (PCMDI) at the Lawrence Livermore National Laboratory, USA. Evaluation on the IPCC AR4 models in simulating the South Asian monsoon (Kripalani et al., $2007 \mathrm{a}, \mathrm{b}$ ) and projections of temperature, precipitation and snow cover area over the southwest Iran by Zarenistanak et al. (2014 a, b) and Dhorde et al. (2014) showed that CNRM, ECHAM and UKMOC models performed well in comparison with other models for this region. These models are also from leading international institutions: CNRM from France, ECHAM from Germany and UKMOC from the United Kingdom. Therefore, these three coupled models were selected for the projection of temperature, precipitation and snow cover area over Iran for the period of 1981-2100 under B1 and A1B emission scenarios. The B1 emission scenario, also known as the 550-ppm stabilization experiment, envisions the slowest growth of anthropogenic greenhouse gas concentrations, followed by the A1B experiment or the 720-ppm stabilization experiment which comes with somewhat more rapid forcing (IPCC, 2007). 
Open access e-Journal

Earth Science India, elSSN: $0974-8350$

Vol. 10 (II), April, 2017, pp. 63- 81

http://www.earthscienceindia.info/

\begin{tabular}{|c|c|c|c|c|c|}
\hline No. & $\begin{array}{l}\text { Originating } \\
\text { group }\end{array}$ & Country & IPCC ID & Abbreviation & Key reference \\
\hline 1 & $\begin{array}{l}\text { Meteo- } \\
\text { France=Centre } \\
\text { National de } \\
\text { Recherches } \\
\text { Meteorologiques }\end{array}$ & France & CNRM-CM3 & CNRM & $\begin{array}{l}\text { Salas-Melia et } \\
\text { al. (2006) }\end{array}$ \\
\hline 2 & $\begin{array}{l}\text { Max Planck } \\
\text { Institute } \\
\text { for Meteorology }\end{array}$ & Germany & $\begin{array}{l}\text { ECHAM5/ } \\
\text { MPI-OM }\end{array}$ & ECHAM & $\begin{array}{l}\text { Jungclaus et al. } \\
(2006)\end{array}$ \\
\hline 3 & $\begin{array}{l}\text { Hadley Centre for } \\
\text { Climate } \\
\text { Prediction and } \\
\text { Research= } \\
\text { Meteorological } \\
\text { Office }\end{array}$ & UK & $\begin{array}{l}\text { UKMO- } \\
\text { HadCM3 }\end{array}$ & UKMOC & $\begin{array}{l}\text { Jones et al. } \\
(2004)\end{array}$ \\
\hline
\end{tabular}

Table-1: Climate models and their key references participating in the IPCC AR4 experiments.

\section{Results and Discussion}

Outputs of three different models for projection of temperature, precipitation and snow cover under two emission scenarios are presented here. As suggested by the IPCC AR4 panel, the mean climate of each model shall be determined by the last 20 years of the "20c3m" experiments. Simulated climatology was compared with the observed climatology based on the period 1981-2000. For comparison between observed data and models outputs, data available at 22 synoptic stations through Iran for period of 1981-2000 were examined. The result of the temperature comparison between the observed data and models data was found close to the observed data, except in the ECHAM model (Fig. 2; temperature). The average ECHAM model was $1.9^{0} \mathrm{C}$ warmer than the observed data. The results of modeling of precipitation data were contrastive: ECHAM model showed annual precipitation less than the observed data, while CNRM and UKMOC models showed annual precipitation more than the observed data (Fig. 2; precipitation).

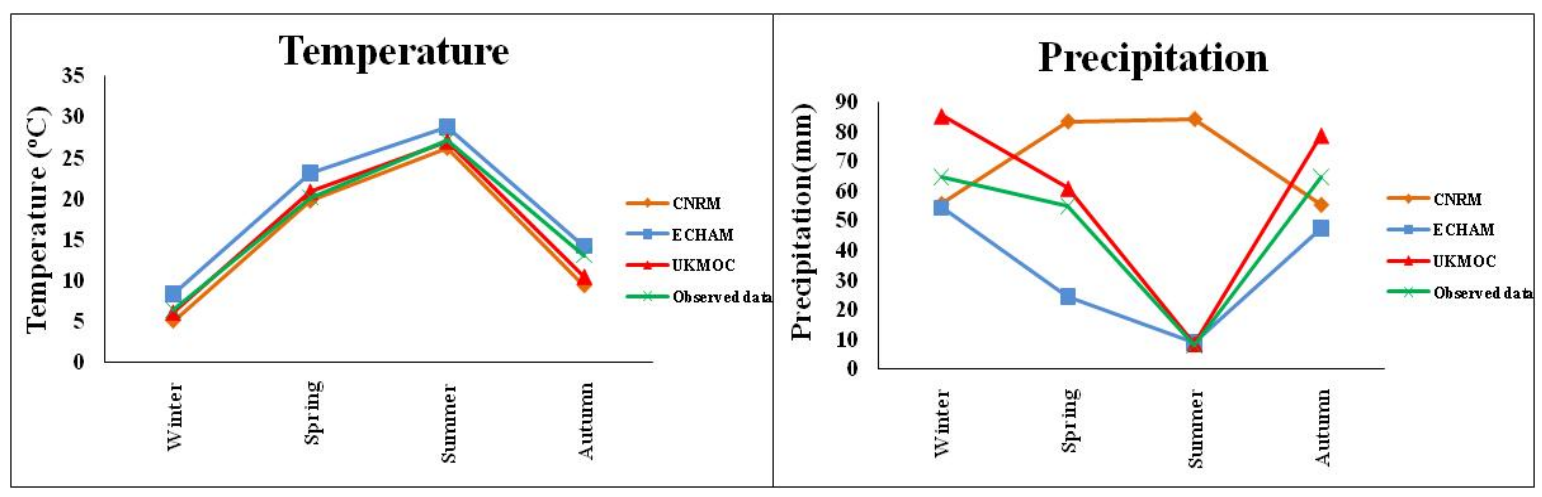

Fig. 2: Average temperature and precipitation in 1981-2000 by observed data and simulated series by the three models. 


\section{Projection of Temperature}

The summaries of annual and seasonal temperature changes between the future and the baseline periods as projected by the three models under both scenarios are presented in Table-2. The results indicated that temperature may increase between 1.27 to $5.38^{0} \mathrm{C}$ by the end of the twenty-first century, depending on model and emission scenarios. All models agreed on a future temperature rise but the rate of increasing depends on the scenario used. The median temperature increase is projected to be higher in summer and spring with more increase occurring in summer, but winter temperature is projected to remain relatively stable (Table-2). Zarenistanak et al. (2014 a) found that summer temperatures may increase with higher rates than spring, winter, and autumn temperatures by 2100 over southwest Iran. Roshan et al. (2011) who used the MAGICC SCENGEN model also indicated highest temperature rise during the warm months over Iran.

Table-2: Projected Temperature $\left({ }^{0} \mathrm{C}\right)$ change for 2081-2100 under B1 and A1B scenario with respect to the baseline simulation of 20c3m (1981-2000).

\begin{tabular}{lllllllllll}
\hline & \multicolumn{9}{c}{ B1 } & \multicolumn{3}{c}{ A1B } \\
\hline & Winter & Spring & Summer & Autumn & Annual & Winter & Spring & Summer & Autumn & Annual \\
\hline CNRM & 1.84 & 2.44 & 2.19 & 2.11 & 2.12 & 3.08 & 3.91 & 3.84 & 3.24 & 3.52 \\
ECHAM & 2.43 & 3.15 & 3.62 & 3.21 & 3.10 & 3.70 & 4.75 & 5.38 & 4.48 & 4.58 \\
UKMOC & 1.91 & 2.52 & 2.65 & 1.27 & 2.09 & 2.95 & 4.33 & 4.79 & 3.22 & 3.82 \\
\hline
\end{tabular}

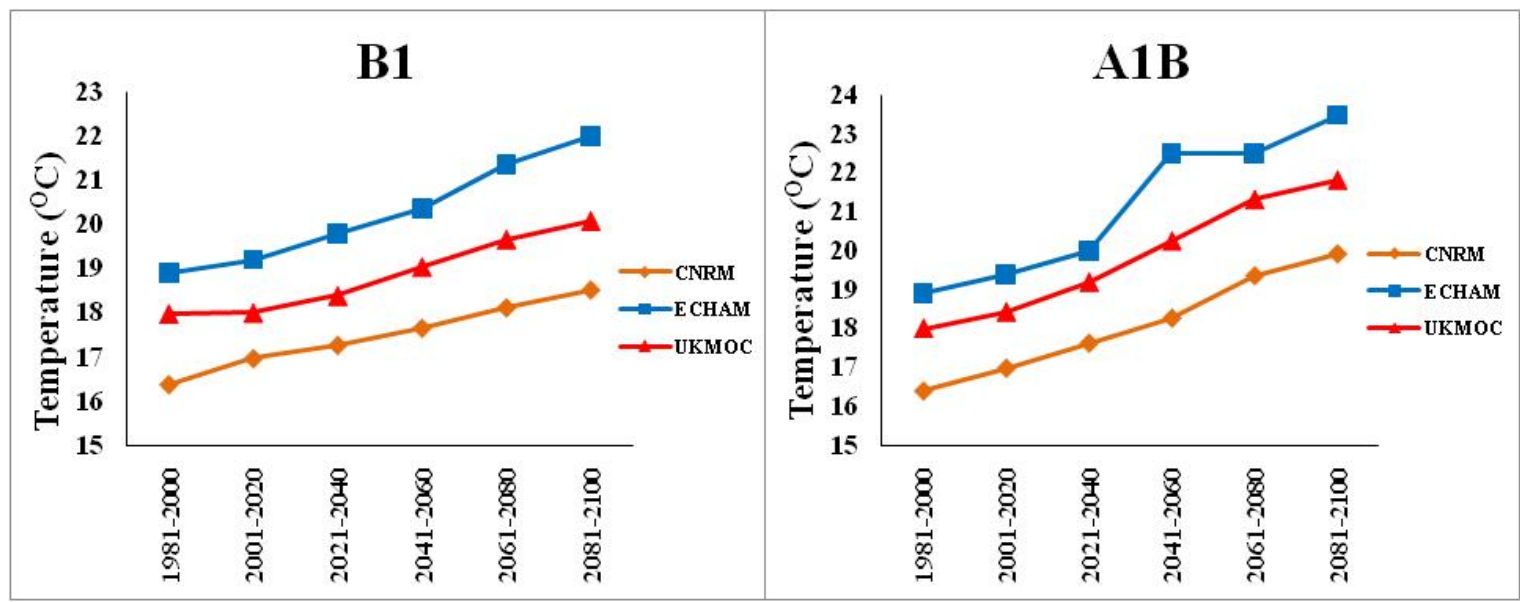

Fig. 3: Projections of annual mean temperature by the three models under B1 and A1B scenarios.

Fig. 3 shows future projections of the annual mean temperature. This rapid increase of the annual mean temperature is projected to begin in the latter half of the $21^{\text {st }}$ century (Fig. 3 ). According to these models and scenarios in the annual scale, CNRM showed less temperature, while ECHAM showed more temperature increase at the end of this century (Fig. 3).

The result of the CNRM model for annual series shows that temperature may increase up to 18.50 and $19.91^{\circ} \mathrm{C}$ in 2100 according to the B1 and $\mathrm{A} 1 \mathrm{~B}$ scenarios, respectively. 
Open access e-Journal

Earth Science India, elSSN: $0974-8350$

Vol. 10 (II), April, 2017, pp. 63- 81

http://www.earthscienceindia.info/

However, the ECHAM model predicted that temperature may increase up to 22.01 and $23.49^{0}$ $\mathrm{C}$ under the $\mathrm{B} 1$ and $\mathrm{A} 1 \mathrm{~B}$ scenarios, respectively, at the end of the twenty-first century. Meanwhile, the UKMOC model expected the temperature to increase up to 20.08 and $21.81^{\circ}$ $\mathrm{C}$ under the B1 and A1B scenarios, respectively (Fig. 3).

The projection of the temperature values for seasonal series using the three models under B1 and A1B scenarios for years 1981-2000, 2001-2020, 2021-2040, 2041-2060, 20612080, and 2081-2100 are depicted in Figs. 4 and 5, respectively.

Future projections of the seasonal temperature indicated that temperature may increase at the end of 2100 (Figs. 4 and 5). The models also predicted that the temperature during the last two decades of twenty-first century would increase more. The temperature increase in spring can cause a change in the melting of snow, and this is very important for agriculture and flood control. Also, rising temperature during the growing season will increase the water requirements of crop and increase water consumption by the year 2100 . Increasing temperature will cause serious adverse effects on food production and shorten the growing season of a variety of plants, which will affect the economy of Iran adversely.

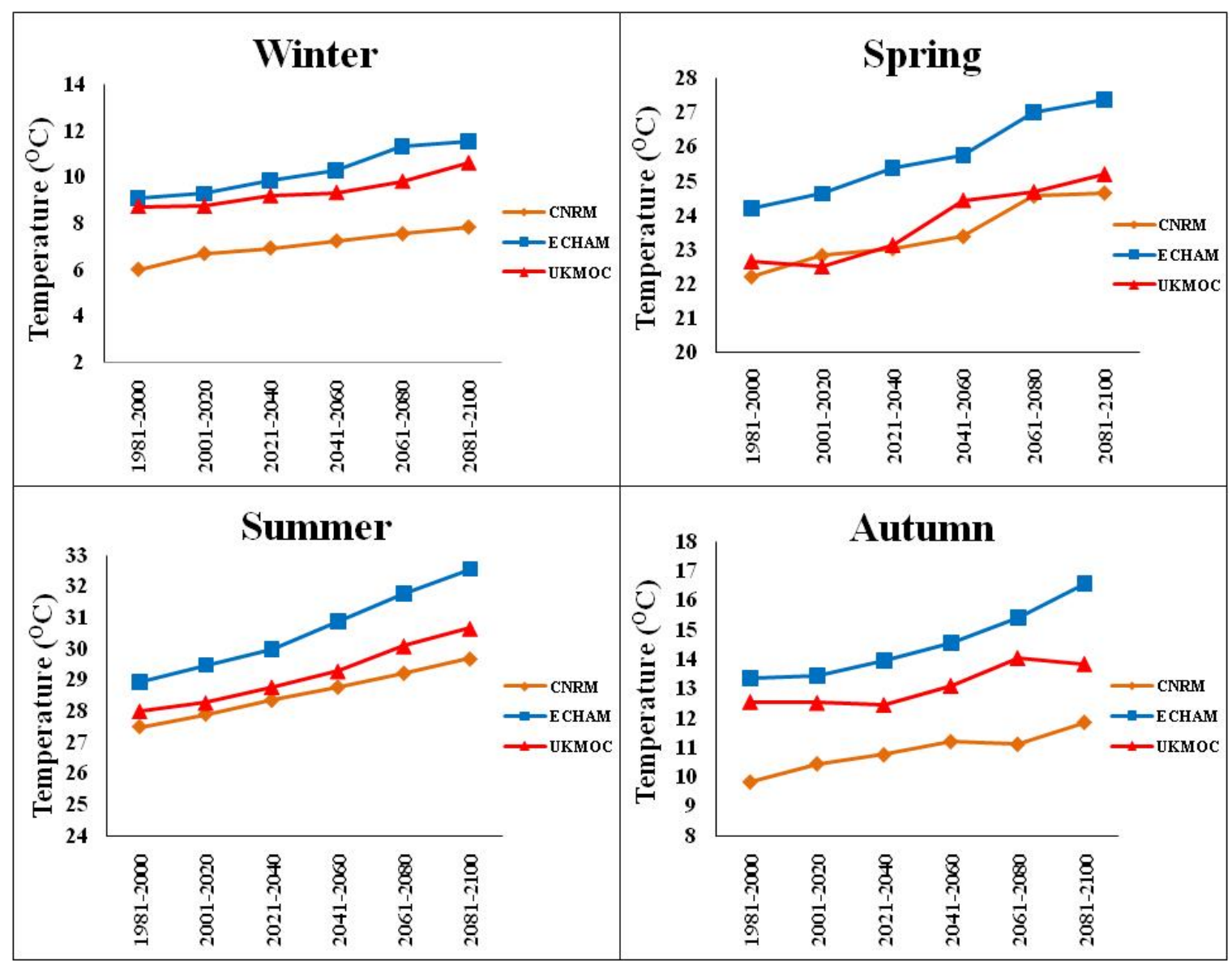

Fig. 4: Projections of seasonal mean temperature under B1emission scenario. 


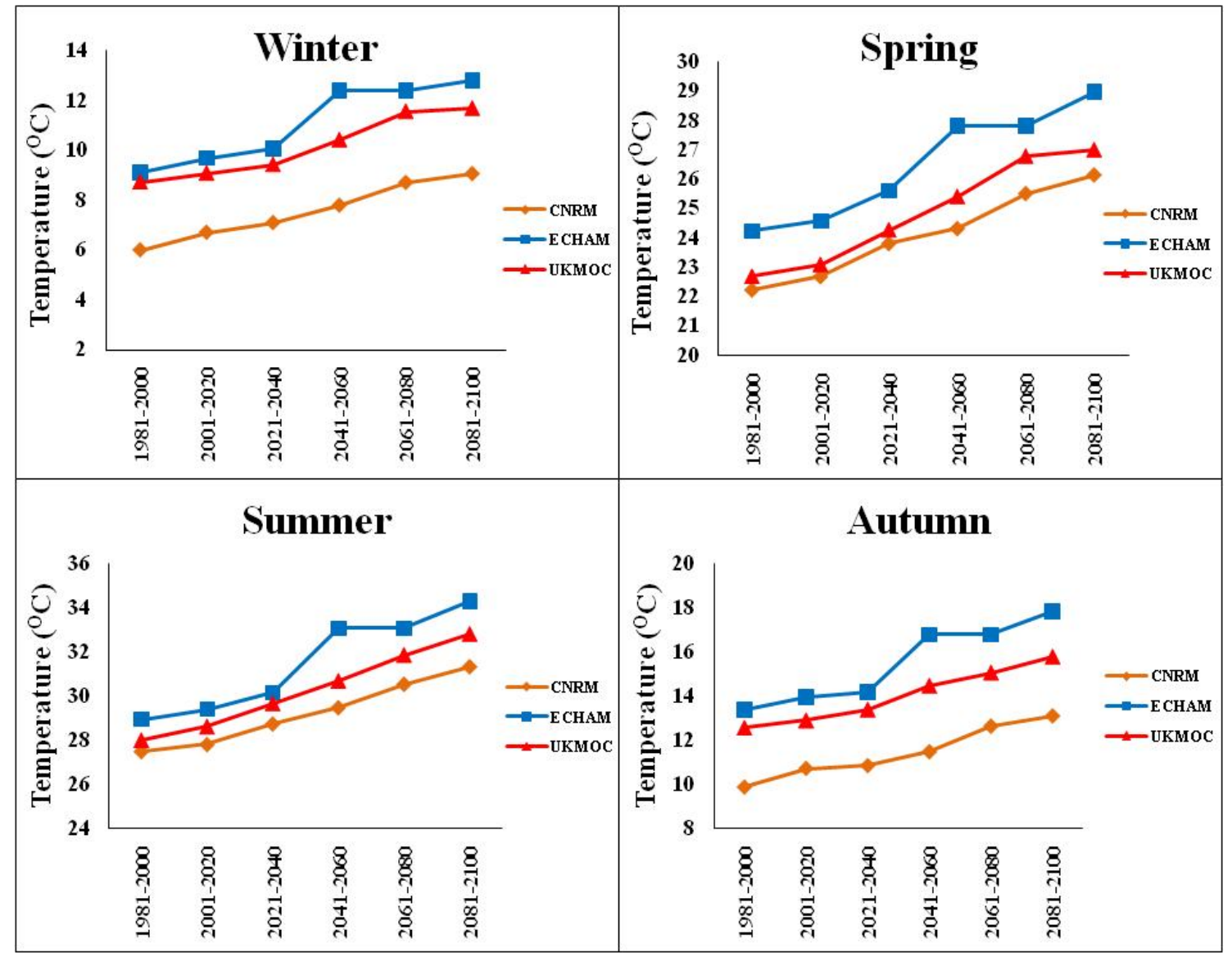

Fig. 5: Projections of seasonal mean temperature under A1B emission scenario.

Babaeian et al. (2010) used the ECHO-G model and the A1 scenario, and found that the highest temperature rise in the future will be in the cold months.

Figs. 6 and 7 illustrate the changes in annual temperature between 2081-2100 and 1981-2000over Iran. Rising pattern of temperature in CNRM model under the B1 and A1B scenarios shows that western, central and southeastern parts of the Iran will have increase in temperature between 2 to $4^{0} \mathrm{C}$ (Figs. 6 and 7). ECHAM model under B1 scenario shows that temperature in western and southeastern parts of the country may increase from 4 up to $5^{0} \mathrm{C}$, while in Caspian Sea coasts, southern coastline, and central Iran, temperature may increase between 2 to $3^{0} \mathrm{C}$ (Fig. 6). According to ECHAM model under A1B scenario all the country will experience rise in temperature with northern coasts and Oman Sea coast in the south having the least rise (Fig. 7). UKMOC model under both scenarios shows that rise temperature will be fastest in northwest parts of the country (Figs. 6 and 7). Western parts of Iran are home to the chief centers of husbandry and water resources. The increasing temperature would severely affect agriculture, livestock industries, and water resources toward the end of the current century. 
Open access e-Journal

Earth Science India, eISSN: $0974-8350$

Vol. 10 (II), April, 2017, pp. 63-81

http://www.earthscienceindia.info/

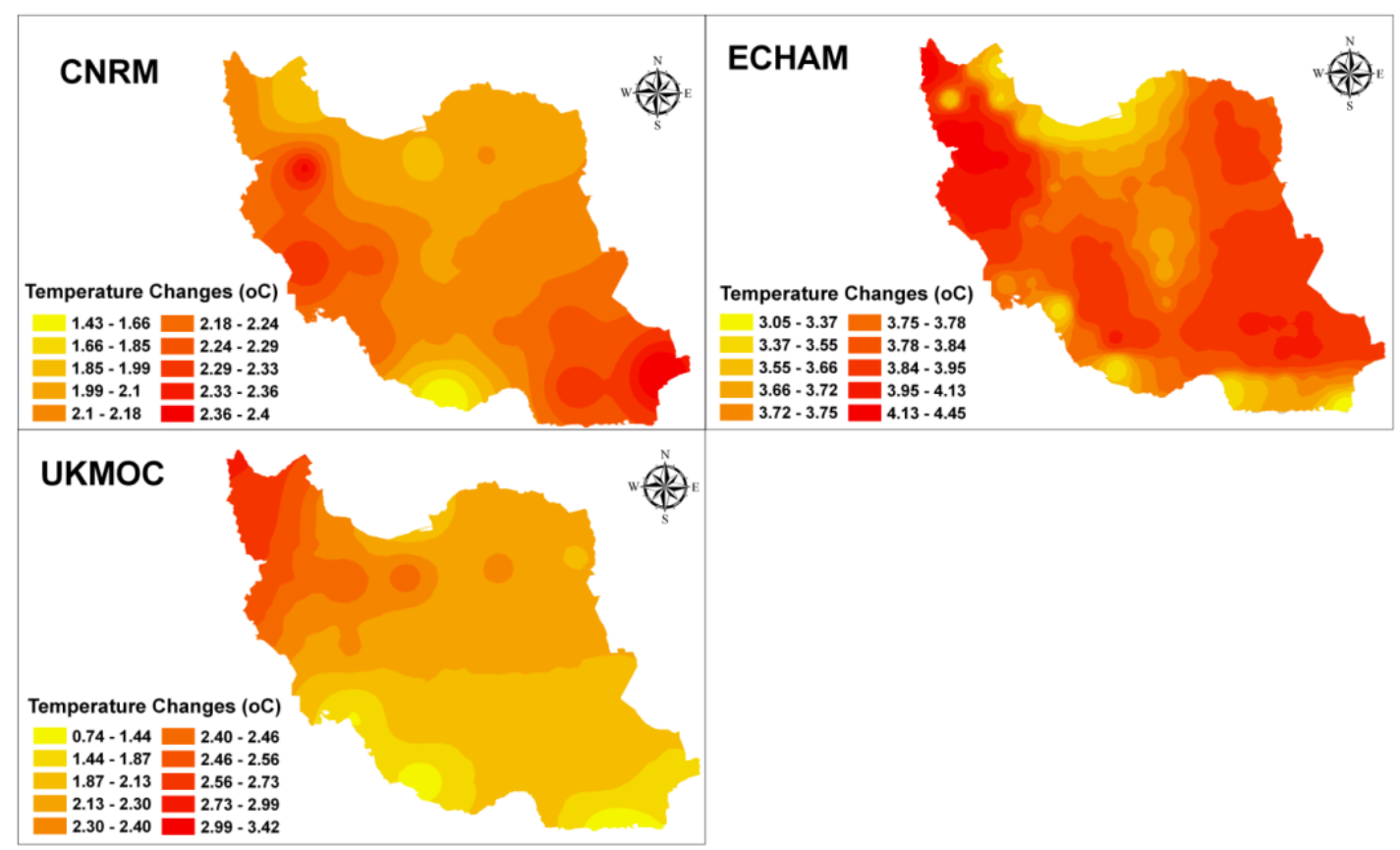

Fig. 6: Projected change in annual mean temperature for the end of $21^{\text {st }}$ century (2081-2100) under B1 scenario with respect to $20 \mathrm{c} 3 \mathrm{~m}$ baseline simulation for the end of the $20^{\text {th }}$ century (1981-2000).

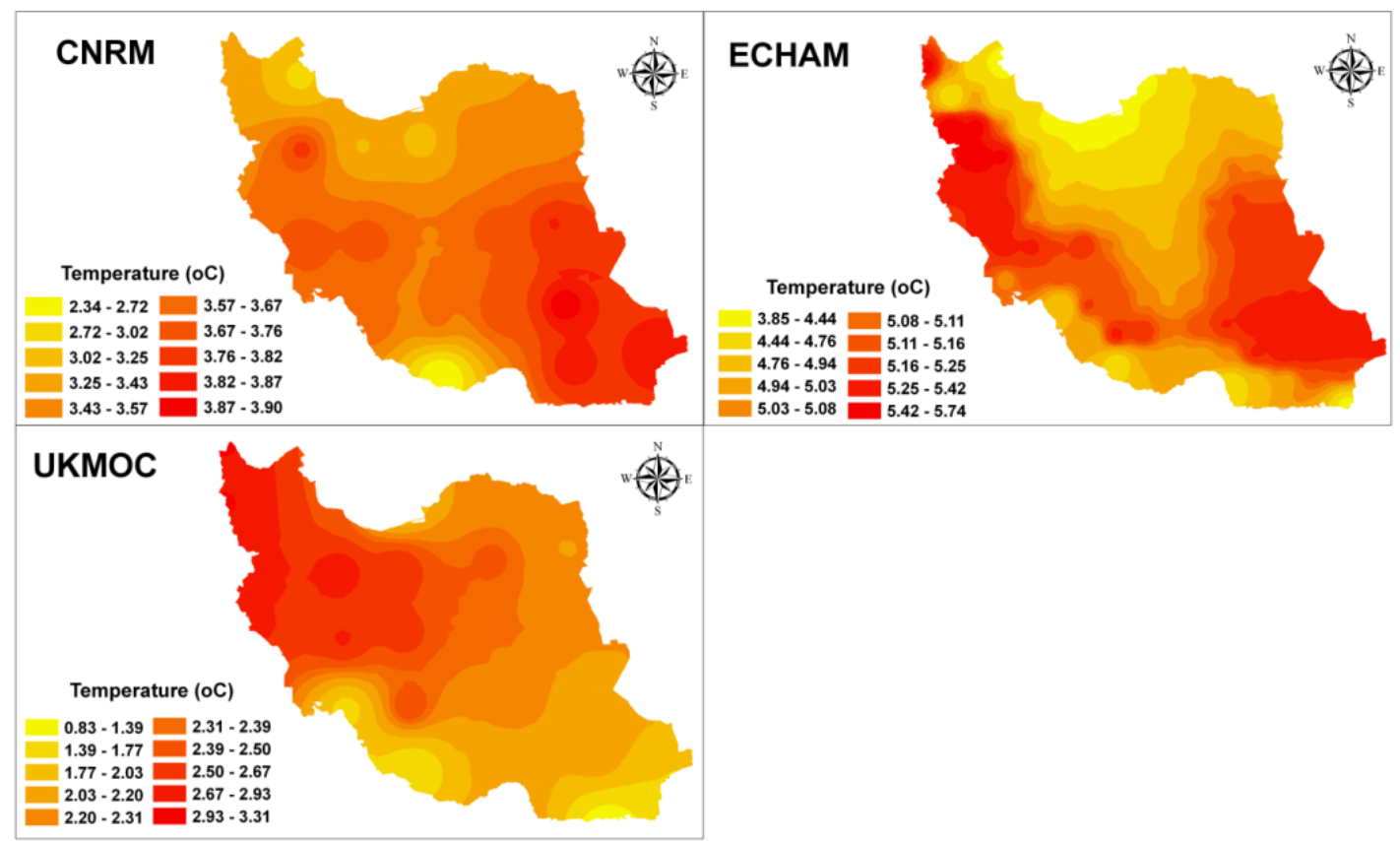

Fig. 7: Projected change in annual mean temperature for the end of $21^{\text {st }}$ century (2081-2100) under A1B scenario with respect to $20 \mathrm{c} 3 \mathrm{~m}$ baseline simulation for the end of the $20^{\text {th }}$ century (1981-2000). 


\section{Projection of Precipitation}

The mean annual and seasonal precipitation changes between the 2081-2100 and baseline (1981-2000) periods, as projected by the three models under both scenarios are summarized in Table-3. In term of future climate, all three models projected decreases in annual precipitation over Iran by 2081-2100 compared to the 1981-2000 baseline period. CNRM model showed that precipitation may decrease by -4.29 and $-16.84 \%$ in 2100 according to the $\mathrm{B} 1$ and $\mathrm{A} 1 \mathrm{~B}$ scenarios, respectively. The result of the ECHAM model showed that precipitation may decrease by $-18.14 \%$ in 2100 according to the B1 scenario, but the A1B scenario indicated decrease in precipitation by $-2.30 \%$ in 2100 .

The result of the UKMOC model showed a decrease in precipitation by -7.33 and $5.40 \%$ in 2100 according to the B1 and A1B scenarios by the end of the twenty-first century, respectively (Table-3). Conversely, not only is Iran situated in an arid and semi-arid region, but it will also face diminishing precipitation, which will affect the economy and agriculture negatively. Dhorde et al. (2014) also reported that precipitation over southwest Iran may decrease at the end of this century according to majority of the models. Fig. 8 shows future projections of the annual precipitation.

Table-3: Projected Precipitation (\%) change for 2081-2100 under B1 and A1B scenario with respect to the baseline simulation of 20c3m (1981-2000).

\begin{tabular}{|c|c|c|c|c|c|c|c|c|c|c|}
\hline \multicolumn{6}{|c|}{ B1 } & \multicolumn{5}{|c|}{ A1B } \\
\hline & Winter & Spring & Summer & Autumn & Annual & Winter & Spring & Summer & Autumn & Annual \\
\hline CNRM & -2.47 & 0.12 & -3.15 & 1.21 & -4.29 & -11.50 & -1.86 & -15.70 & 12.23 & -16.84 \\
\hline ЕСНАМ & -7.03 & -7.37 & -3.42 & -0.31 & -18.14 & -7.47 & -5.18 & -3.81 & 14.16 & -2.30 \\
\hline UKMOC & -7.79 & -4.30 & -1.66 & 6.42 & -7.33 & 10.32 & -18.22 & -2.64 & 5.13 & -5.40 \\
\hline
\end{tabular}

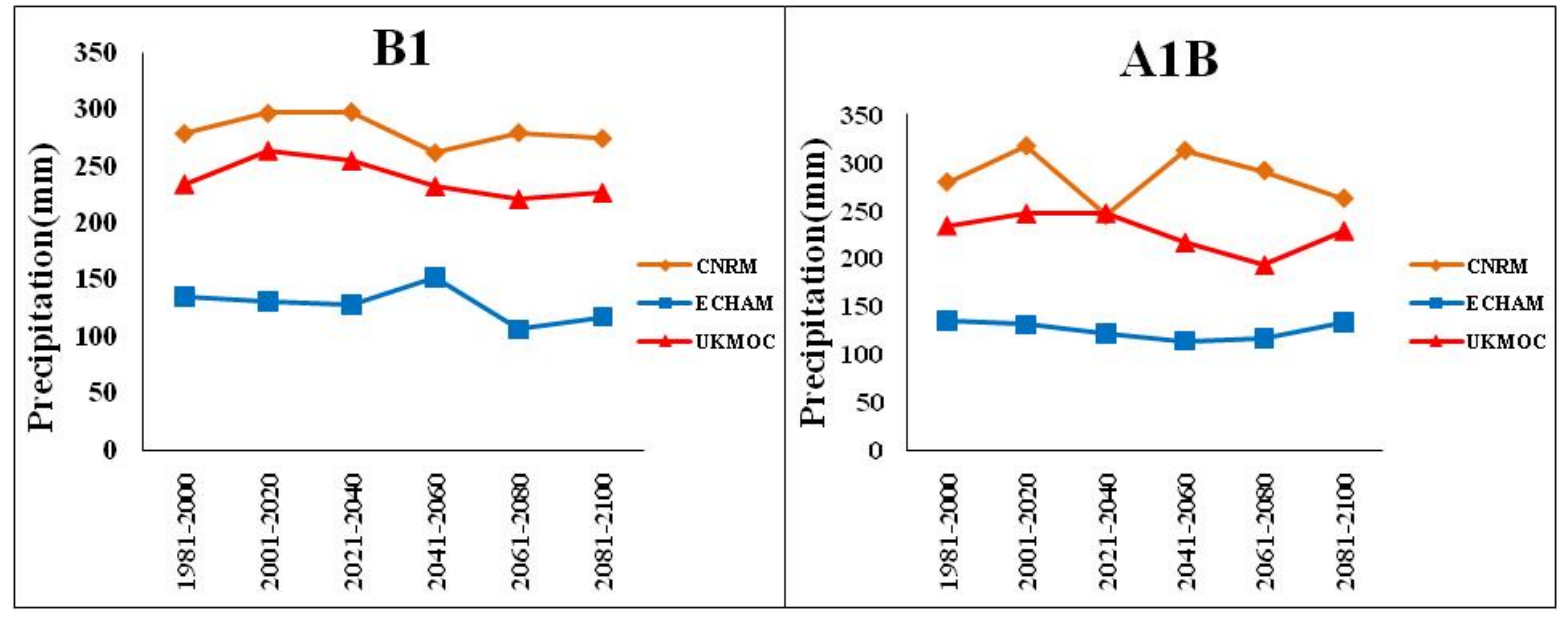

Fig.8: Projections for annual precipitation by the three models under B1 and A1B scenarios. 
Open access e-Journal

Earth Science India, elSSN: $0974-8350$

Vol. 10 (II), April, 2017, pp. 63- 81

http://www.earthscienceindia.info/

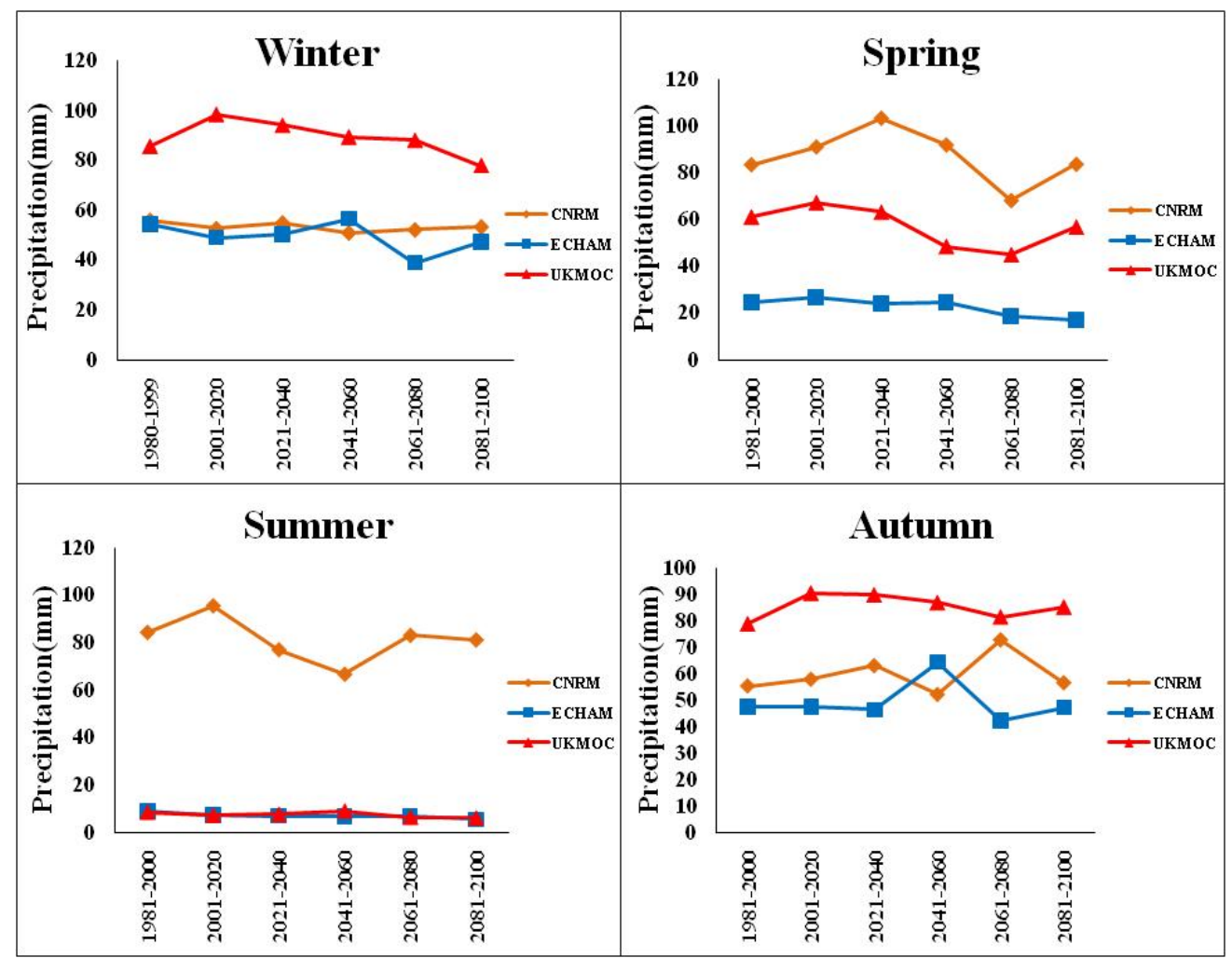

Fig.9: Projections of seasonal precipitation under B1emission scenario.

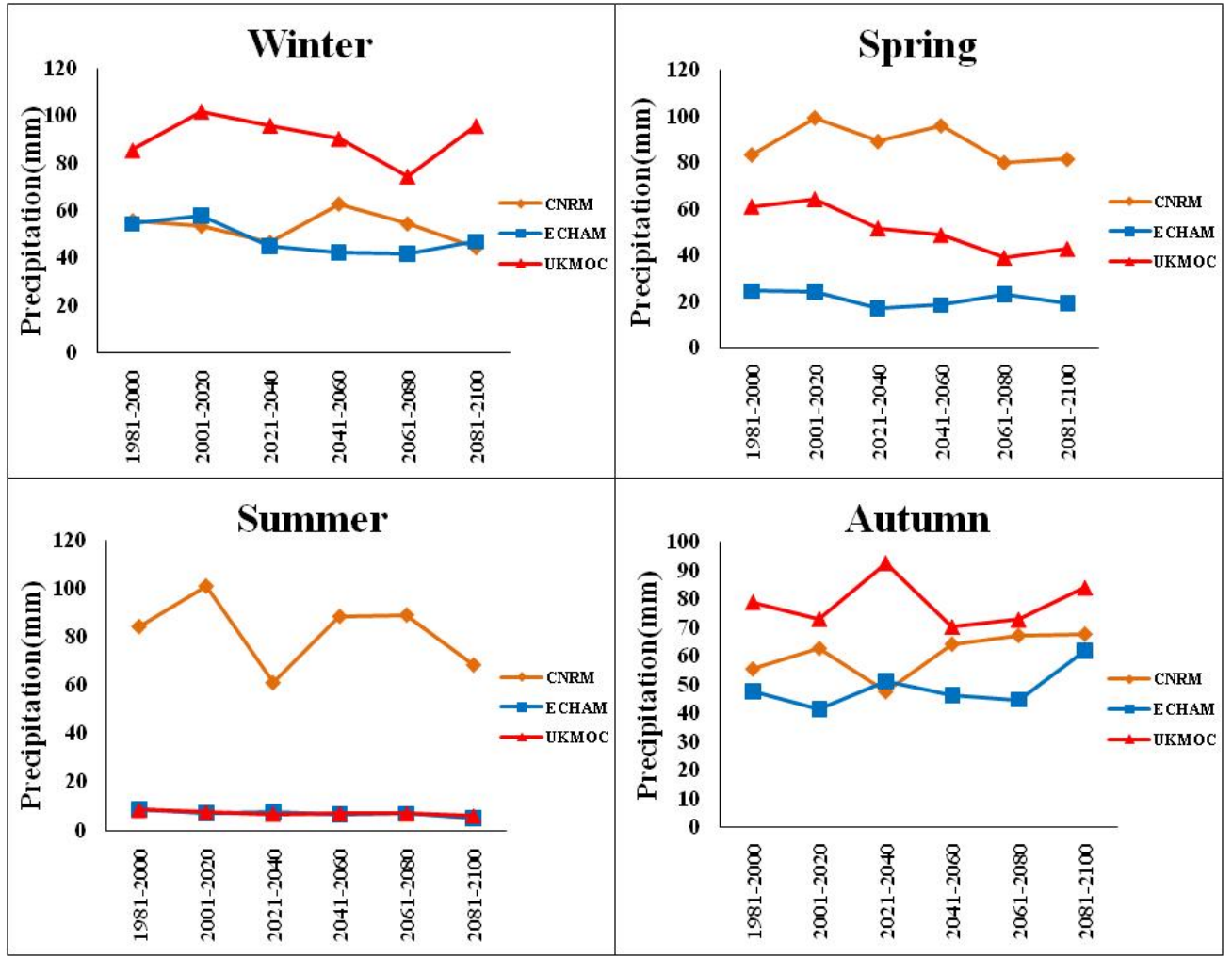

Fig.10: Projections of seasonal precipitation under A1B emission scenario. 
The projection of the precipitation values for seasonal series using the CNRM, ECHAM, and UKMOC models under B1 and A1B emission scenarios for years 1981-2000, 2001-2020, 2021-2040, 2041-2060, 2061-2080, and 2081-2100 are depicted in Fig. 9 and 10.

The models suggested that in winter, spring and summer precipitations may decrease but increase in autumn (Table-3). Summer precipitation projections appeared to be consistent among the CNRM and UKMOC but changes predicted in the ECHAM model appeared to be higher (Figs. 9 and 10). Roshan and Grab (2012) indicated that precipitation would increase by $36 \%$ by the year 2100 . Roshan et al. (2012) projected changes in annual precipitation for 2025 and 2050 compared to that in 2005 , indicating an increase of $25.19 \%$ and $26.4 \%$, respectively. Figs. 11 and 12 illustrate the changes in annual precipitation between 20812100 and 1981-2000 over Iran. Precipitation is projected to increase in north east of Iran and will decrease in the coastal regions of the Oman Sea under B1 scenario in CNRM model. In ECHAM model, precipitation is projected to increase more in the northwest and southeast parts of Iran in comparison to other parts of Iran. Precipitation is projected to increase more in whole of Iran according to the UKMOC model (Fig. 11), while precipitation will decrease more in the coastal regions of the Persian Gulf and Oman Sea in CNRM model under A1B scenario in comparison to other parts of Iran. ECHAM model projected that precipitation will increase in the southwest part of Iran and will decrease in northwest and east of Iran. Precipitation is also projected to increase in the central part of Iran according to the UKMOC model (Fig. 12).

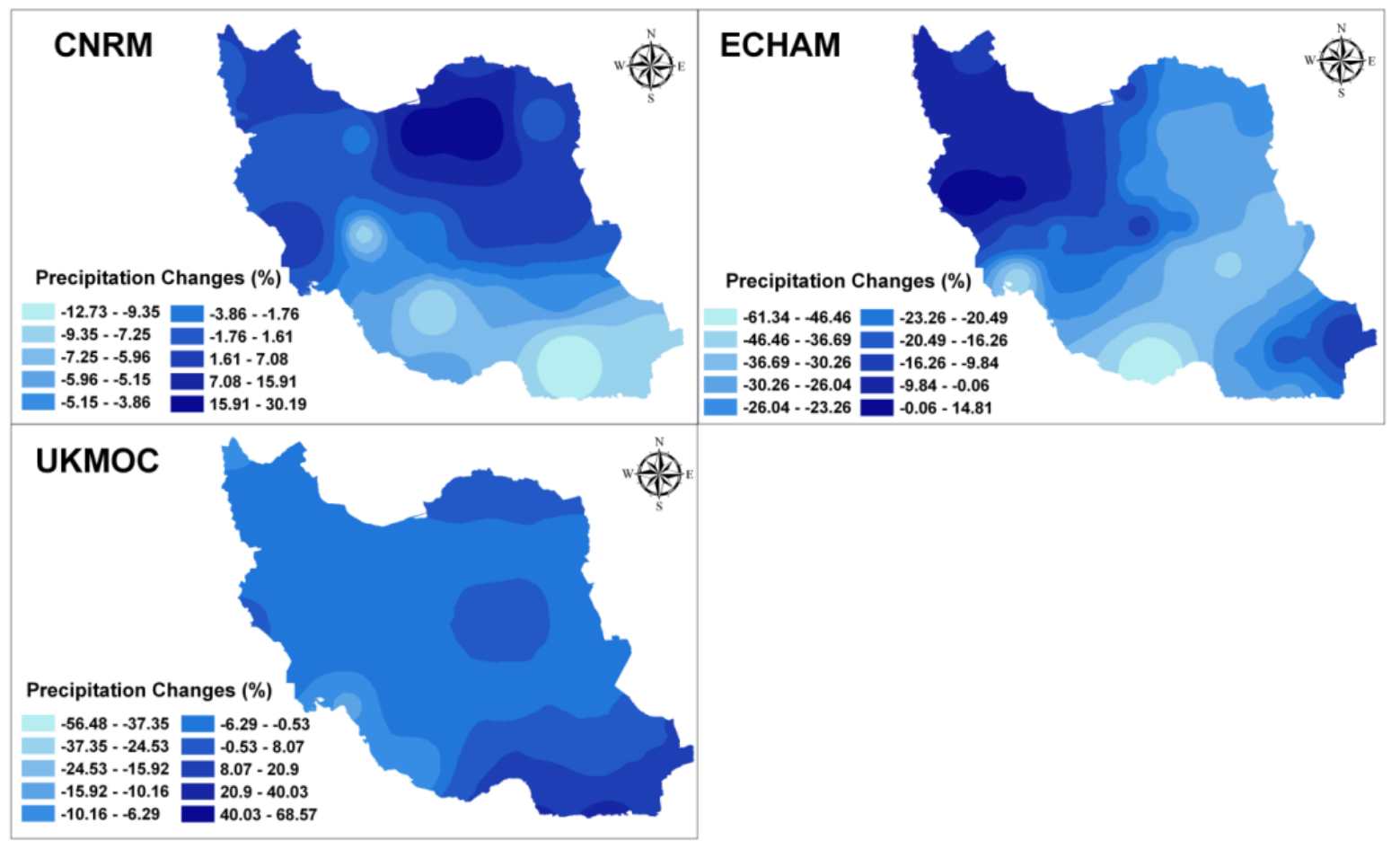

Fig. 11: Projected change in annual mean precipitation for the end of $21^{\text {st }}$ century (20812100 ) under B1 scenario with respect to $20 \mathrm{c} 3 \mathrm{~m}$ baseline simulation for the end of the $20^{\text {th }}$ century (1981-2000). 


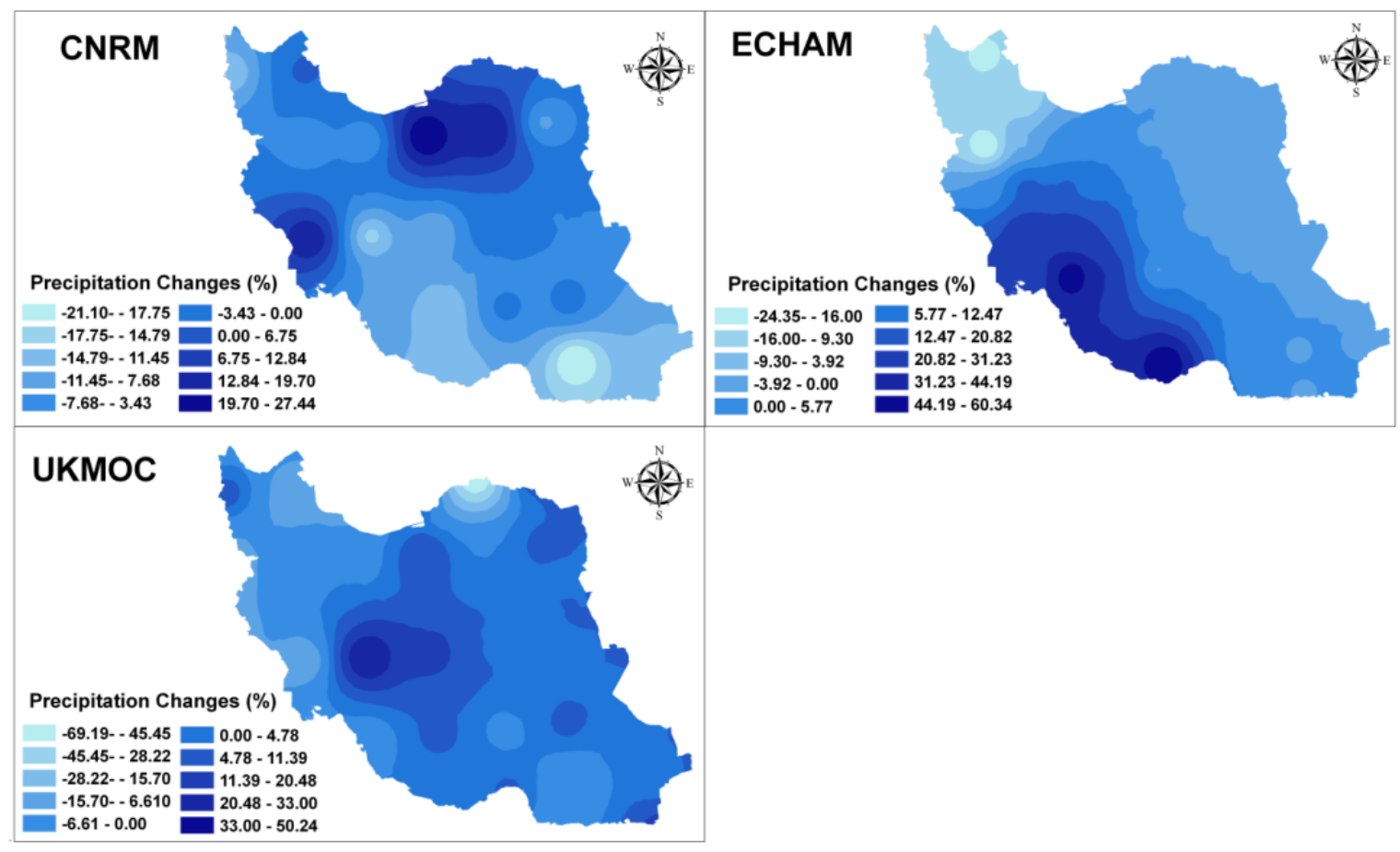

Fig. 12: Projected change in annual mean precipitation for the end of $21^{\text {st }}$ century (20812100 ) under A1B scenario with respect to $20 \mathrm{c} 3 \mathrm{~m}$ baseline simulation for the end of the $20^{\text {th }}$ century (1981-2000).

\section{Projection of Snow Cover}

In this study, snow cover projection was conducted during December, January, February, March and April as snow cover-observed months. The results of snow cover area projection by all the models indicated that snow cover area might decrease under both scenarios at the end of twenty-first century over Iran (Table-4). Kripalani et al. (2007a) observed decreases in Eurasian snow fall, in particular over western Eurasia and the Tibetan Plateau for the end of twenty-first century.

Table-4: Projected changes in snow cover area $\left(\mathrm{km}^{2}\right)$ change for 2081-2100 under B1 and A1B scenario with respect to the baseline simulation of 20c3m (1981-2000).

\begin{tabular}{|c|c|c|c|c|c|c|c|c|c|c|}
\hline \multicolumn{6}{|c|}{ B1 } & \multicolumn{5}{|c|}{ A1B } \\
\hline & Dec. & Jan. & Feb. & March & April & Dec. & Jan. & Feb. & March & April \\
\hline CNRM & -92253 & 281498 & 197817 & 181346 & -67745 & -65496 & 108851 & 371223 & 246014 & 208052 \\
\hline ЕСНАМ & 338233 & -99776 & 106511 & 406786 & 225900 & 448875 & 269624 & 279595 & 421271 & 123736 \\
\hline UKMOC & 272374 & 359626 & 258218 & 225719 & 246798 & -80009 & 17769.4 & 467336 & 404187 & 131200 \\
\hline
\end{tabular}

The snow cover area was projected using the 3 models under B1 and A1B scenarios for years 1981-2000, 2001-2020, 2021-2040, 2041-2060, 2061- 2080, and 2081-2100, as depicted in Figs. 13 and 14. 


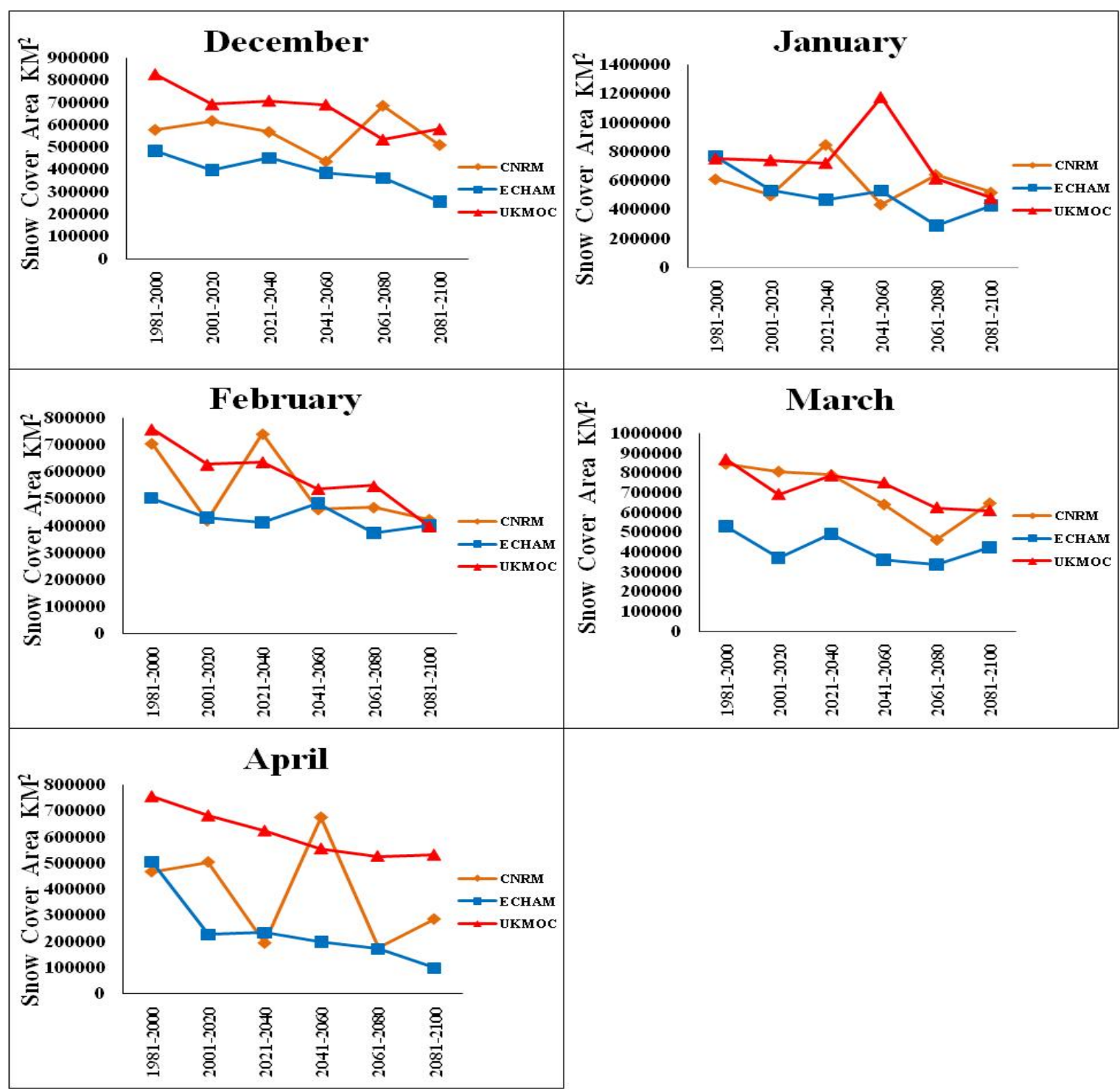

Fig. 13: Projections for snow cover area under B1 emission scenario.

Figs. 15 and 16 show changes in snow cover area between 2081-2100 and 1981-2000 over Iran. The snow cover area will decrease during December, January, February, March and April towards the end of this century. The result of snow cover area projection showed that ECHAM indicated more changes in comparison with other models, and the CNRM model indicated less change in comparison with other models. The highest changes over the snow cover would occur in March and February, within the range of -271284 and -372718 $\mathrm{km}^{2}$, respectively; on the contrary, the least changes may emerge in January and April, within -180148 and $-132081 \mathrm{~km}^{2}$, respectively (Table-4). 


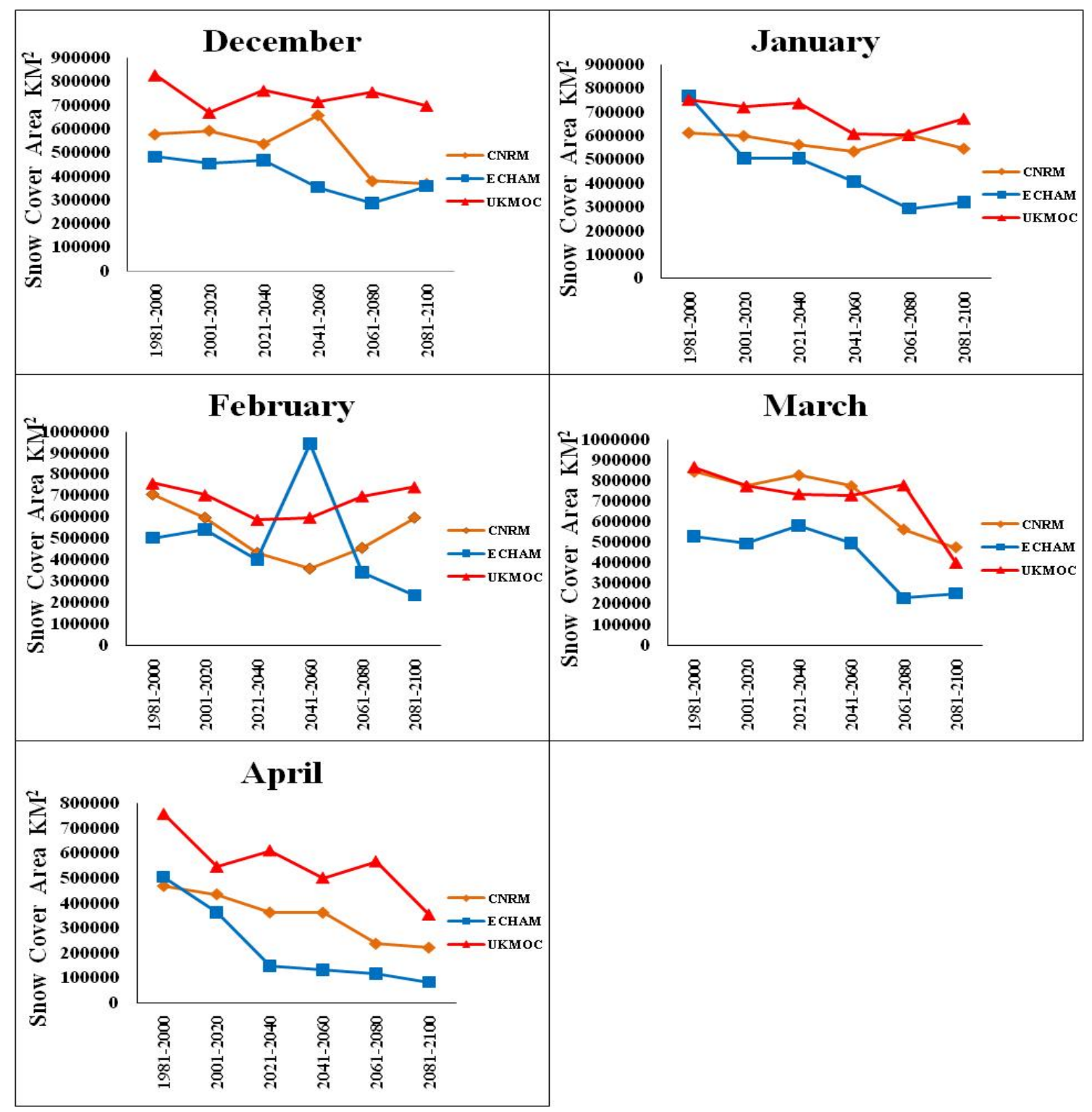

Fig. 14: Projections for snow cover area under A1B emission scenario.

In temperature projection section I already found that temperature in western parts would increase more than other regions, a fact that would affect snow coverage. As for the highland regions in western Iran is concerned, the main water resources, keenly dependent on the snow, may encounter water discharge subdue due to low snow cover toward the end of the current century. The decrease in snow cover area would directly affect agriculture, water resources, and national industries. Zarenistanak et al. (2014 b) conducted a snow cover projection, which showed that snow cover area may decrease over southwest Iran at the end of this century as indicated by all the models.

The present models and scenarios depict that Iran will experience temperature increment as result due to the snow cover, with heavy negative implications since it affects river discharge and water resources at the dams due to subterranean water resources with diminishing water quality and quantity. Moreover, the scale of water discharges may 
intensify in winter, because the temperature may increase and reach the threshold of snow melting with temperature of $2.4^{0} \mathrm{C}$. As a result, the river discharge will be more furious in middle of winter. Meanwhile, there is no change in the scale of precipitation in winter, therefore the river discharge is normal in spring, in spite of snow resource decrement.

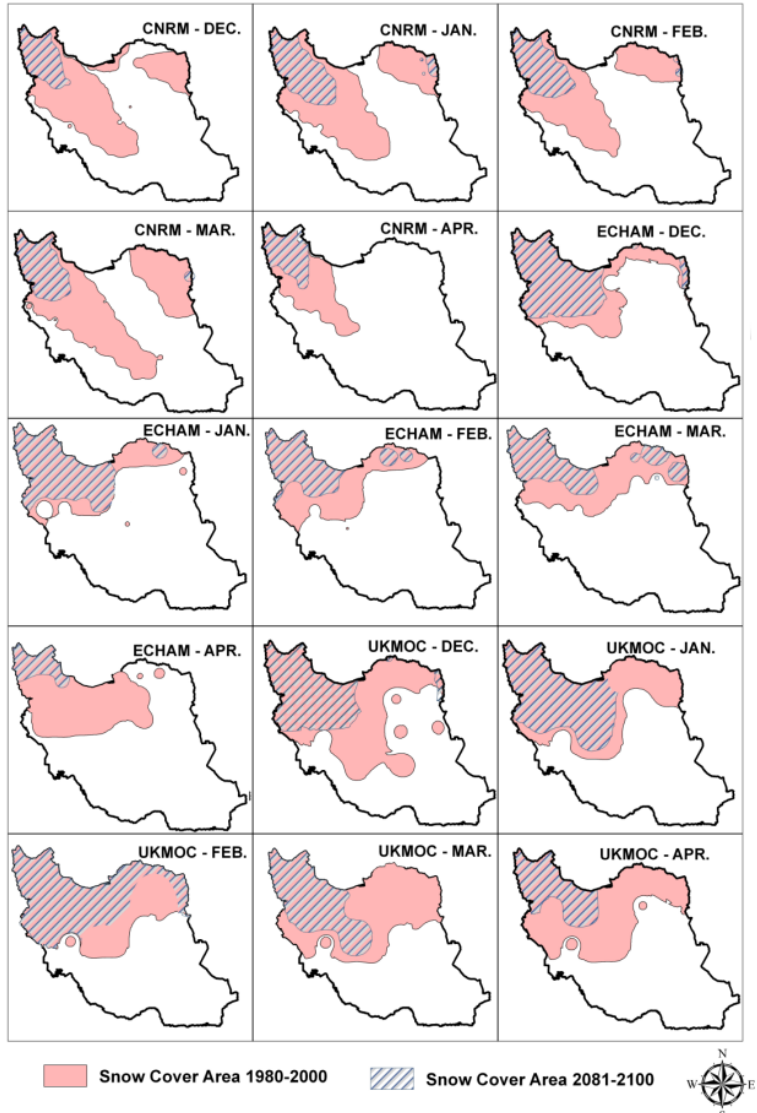

Fig. 15: Projected change in snow cover area for the end of $21^{\text {st }}$ century (2081-2100) under B1 scenario with respect to $20 \mathrm{c} 3 \mathrm{~m}$ baseline simulation for the end of the 20th century (1981-2000).

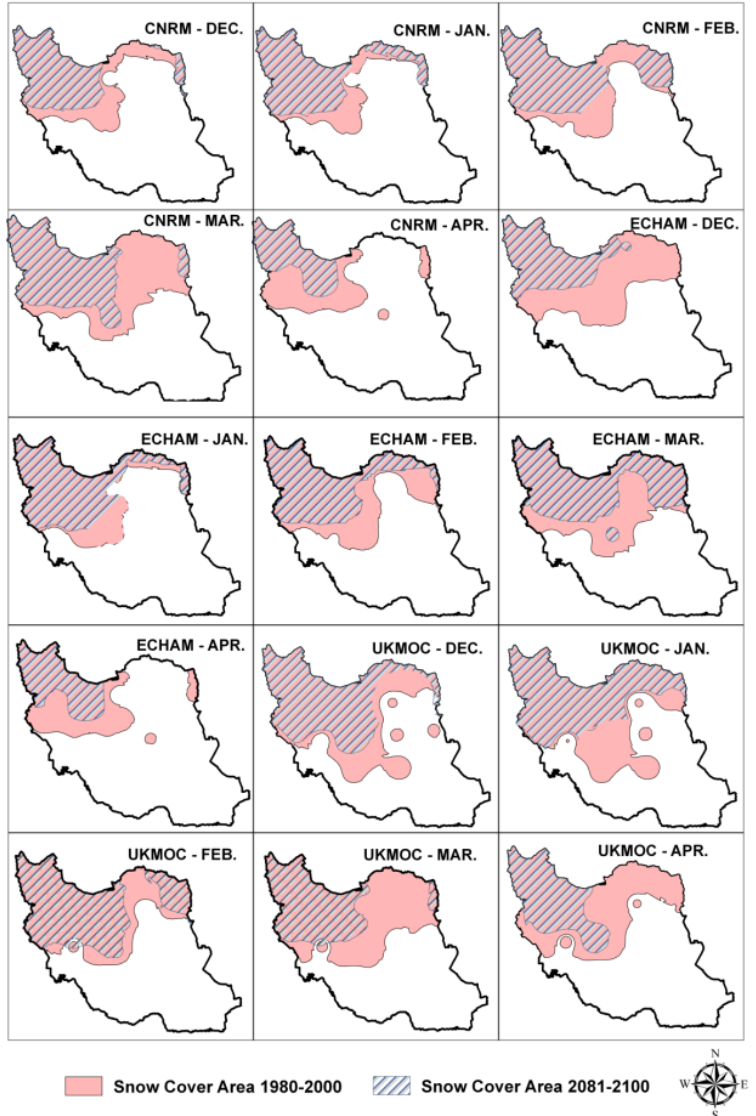

Fig. 16: Projected change in snow cover area for the end of $21^{\text {st }}$ century $(2081-2100)$ under A1B scenario with respect to $20 \mathrm{c} 3 \mathrm{~m}$ baseline simulation for the end of the 20th century (1981-2000).

\section{Conclusions}

These study analyses on projections of temperature, precipitation and snow cover area over Iran for the $21^{\text {st }}$ Century under the Intergovernmental Panel on Climate Change AR4 showed that temperature may increase between 1.24 to $5.38^{0} \mathrm{C}$ by 2100 in the study area. Future projections of annual precipitation under B1 and A1B scenario reveal that precipitation may decrease according to all models, except in autumn, where the precipitation may increase by $2.44 \%$ and $10.50 \%$ under B1 and A1B scenarios. On an average, the annual precipitation may decrease by $-9.92 \%$ under B1 scenario and $-8.18 \%$ under A1B scenario. According to all the models, the projections of snow cover reveal that snow cover may decrease under both scenarios at the end of twenty-first century, with decrease of -224040 and $-242883 \mathrm{~km}^{2}$ under B1 and A1B scenarios, respectively, compared to the baseline (19812000). 
Open access e-Journal

Earth Science India, eISSN: $0974-8350$

Vol. 10 (II), April, 2017, pp. 63- 81

http://www.earthscienceindia.info/

Spatial variation in annual temperature between 2081-2100 and 1981-2000 over Iran shows larger temperature increase in central and western parts of Iran, in comparison to the coastal regions of the Persian Gulf and Oman Sea and coastal part of Caspian Sea in north of Iran. However, the variations of the annual precipitation between 2081-2100 and 1981-2000 will not be uniform over the Iran and there may appear various patterns (with increasing and decreasing zones). Snow cover area during December, January, February, March and April shows that the northern half of the country shall witness snow coverage in the late current century while the southern area shall face no snow cover.

It is predicted that Iran shall face semi-arid and arid climate due to temperature increment and precipitation diminishment by late current century. Consequently, it is important to innovate an effective strategy under logical management over water resources and improvement of water utilization specifically in agricultural sector, on account of temperature and evaporation and perspiration. Therefore, the future plans should develop a strategy to hold Iran's water shedding safe in order to stop any harmful changes in term of water resources. Since one those sectors ought to stay with compatible scenario under productive improvement specifically in the agriculture sector. Otherwise the agriculture shall face heavily changes, it is wise to maintain and keep adaptable strategy to encounter new circumstances that may change the structure of regional culture. Since it is evident that water distribution shall face changes in future, it is necessary to develop prospective plans in the field of water allocation with more flexibility in future.

Acknowledgements: The author would like to express gratitude to the modeling groups for providing their data for analysis, the Program for Climate Model Diagnosis and Intercomparison (PCMDI), Lawrence Livermore National Laboratory, USA, for collecting and archiving the model output, and providing necessary data required for the study. Acknowledgement is also given to the Islamic Republic of Iran Meteorological Organization (IRIMO) for providing observed data.

\section{References}

Babaeian, I., Najafi-Nik, Z., Zabolabbassi, F., HabibiNokhandan, M., Adab, H. and Malbousi, S. (2010) Climate change assessment over Iran during 2010-2039 by using statistical downscaling of ECHO-G model. Journal of Climate Research, v.16, pp.136-152 (in Persian).

Bartholy, J. and Pongracz, R. (2010) Analysis of precipitation conditions for the Carpathian Basin based on extreme indices in the 20th century and climate simulations for 2050 and 2100. Phys. Chem. Earth, v. 35, pp. 43-51.

Callaghan, T.V., Johansson, M., Brown, R.D., Groisman, P.Y., Labba, N., Radionov, V., Bradley, R.S., Blangy, S., Bulygina, O.N., Christensen, T.R., Colman, J.E., HEssery, R.L., Forbes, B.C.and Forchhammer, M.C.et al. (2011) Multiple effects of changes in arctic snow cover. AMBIO, v. 40, pp. 32-45.

Dash, S. K., Saraswat, V., Panda, S.K. and Sharma, N. (2013) A study of changes in rainfall and temperature patterns at four cities and corresponding meteorological subdivisions over coastal regions of India. Global Planet. Change, v. 108, pp. 175-194.

Dash, S. K., Sharma, N., Pattnayak, K. C., Gao, X. J. and Shi, Y. (2012) Temperature and precipitation changes in the north-east India and their future projections. Global Planet. Change, v. 98-99, pp. 31-44.

De'ry, S. J., Stieglitz, M., McKenna, E. C. and Wood, E. F. (2005) Characteristics and trends of river discharge into Hudson, James, and Ungava bays, 1964-2000. J. Climate, v. 18, pp. 2540-2557.

Dhorde, A., Zarenistanak, M., Kripalani, R. H. and Preethi, B. (2014) Precipitation analysis over southwest Iran: trends and projections. Meteor. Atmos. Phys., v. 124, pp. 205-216.

Dibike, Y., Prowse, T., Shrestha, R. and Ahmed, R. (2012) Observed trends and future projections of precipitation and air temperature in the Lake Winnipeg watershed. J. Great Lakes Res., v. 38, pp. 7282. 
Faggian, P. and Giorgi, F. (2009) An analysis of global model projections over Italy, with particular attention to the Italian Greater Alpine Region (GAR). Clim. Chang., v. 96 pp. 239-258.

Gobiet, A., Kotlarski, S., Beniston, M., Heinrich, G., Rajczak, J. and Stoffel, M. (2014) $21^{\text {st }}$ century climate change in the European Alps- A review. Sci., Total Environ., v. 439, pp. 1138-1151.

IPCC (2007) Climate Change 2007: The physical science basis. Solomon, S., Quin, D., Manning, M., Chen, X., Marquis, M., Averyt, K.B., Tignor, H. L., Miller, M. (eds.) Contribution of Working Group I to the Fourth Assessment Report of the Intergovernmental Panel on Climate Change. Cambridge University Press, Cambridge, 996p.

Jones, C., Gregory, J., Thorpe, R., Cox, P., Murphy, J., Sexton, D. and Valdes, H. (2004) Systematic optimization and climate simulation of FAMOUS, a fast version of HADCM3. Hadley Centre Technical, Note 60.

Jungclaus, J. H., Keenlyside, N., Botzet, M., Haak, H., Luo, J. J., Latif, M., Marotzke, J., Mikolajewicz, U. and Roeckner, E. (2006) Ocean circulation and tropical variability in the coupled model ECHAM5 = MPIOM. J. Climate, v. 19 pp. 3952-3972.

Jylhä, K., Fronzek, S., Tuomenvirta, H., Carter, R. and Ruosteenoja, K. (2008) Changes in frost, snow and Baltic sea ice by the end of the twenty-first century based on climate model projections for Europe. Clim. Chang., v. 86, pp. 441-462.

Kousari, M. R., Ekhtesasi. M. R., Tazeh. M., Saremi, M. A. and Asadi, M. A. (2011) An investigation of the Iranian climatic changes by considering the precipitation, temperature, and relative humidity parameters. Theor. Appl. Climatol., v.103, pp. 321-335.

Kripalani, R. H., Oh, J. H. and Chaudhari, H. S. (2007a) Response of the East Asian summer monsoon to doubled atmospheric $\mathrm{CO}_{2}$ : coupled climate model simulations and projections under IPCC AR4. Theor. Appl. Climatol., v. 87, pp. 1-28.

Kripalani, R. H., Oh, J. H., Kulkarni, A., Sabade, S. S. and Chaudhari, S. (2007b) South Asian summer monsoon precipitation variability: coupled climate model simulations and projections under IPCC AR4. Theor. Appl. Climatol., v. 90, pp. 133-159.

Levine, R., Turner, A., Marathayil, D. and Martin, G. (2013) The role of northern Arabian Sea surface temperature biases in CMIP5 model simulations and future projections of Indian summer monsoon rainfall. Clim. Dyn., v. 41, pp. 155-172.

Osca, J., Romero, R. and Alonso, S. (2013) Precipitation projections for Spain by means of a weather typing statistical method. Global Planet. Change, v. 109, pp. 46-63.

Park, H., Fedorov, A., Zheleznyak, M. N., Konstantinov, P. and Walsh, J. (2014) Effect of snow cover on panArctic permafrost thermal regimes. Clim. Dyn., DOI: 10.1007/s00382-014-2356-5.

Ragab, R. and Prudhomme. C. (2002) Climate change and water resources management in arid and semi-arid regions: prospective and challenges for the 21st century. Biosystems Engineering, v. 81, pp. 3-34.

Ribalaygua, J., Pino, M., Pórtoles, J., Roldán, E., Gaitán, E., Chinarro, D. and Torres, L. (2013) Climate change scenarios for temperature and precipitation in Aragón (Spain). Science of the Total Environment,v. 463-464, pp. 1015-1030.

Roshan, G. R. and Grab, S. W. (2012) Regional climate change scenarios and their impacts on water requirements for wheat production in Iran. International Journal of Plant Production, v. 6(2), pp. 239266.

Roshan, G.R., Khoshakh, Lagh, F., Azizi, G. H. and Mohammadi, H. (2011) Simulation of temperature changes in Iran under the atmosphere carbon dioxide duplication condition. Journal of Environmental Health Science and Engineering, v. 8, pp. 139-152.

Roshan, G.R., Khoshakhlagh, F. and Azizi, G. (2012) Assessment of suitable general atmosphere circulation models for forecasting temperature and precipitation amounts in Iran under condition of global warming. Geography and development, v. 27, pp. 5-7.

Salas-Melia, D., Chauvin, F., Deque, M., Douville, H., Gueremy, J.F., Marquet, P., Planton, S., Royer, J.F. and Tyteca, S. (2006) Description and validation of the CNRM-CM3 global coupled model. Note, de centre GMGEC CNRM France. Clim. Dyn. v. 30, pp. 123-139.

Senatore, A., Mendicino, G., Smiatek, G. and Kunstmann, H. (2011) Regional climate change projections and hydrological impact analysis for a Mediterranean basin in Southern Italy. J. Hydrol., v. 399, pp. 70-92.

Tabari, H., Hosseinzadeh, Talaee, P., Ezani, A. and Shifteh and Some'e, B. (2012) Shift changes and monotonic trends in autocorrelated temperature series over Iran. Theor. Appl. Climatol., v. 109, pp. 95-108.

Terray, L. and Boe.J.(2013) Quantifying $21^{\text {st }}$ century France climate change and related uncertainties. Comptes. Rendus Geoscience, v. 345, pp. 136-149.

Callaghan, T. V., Johansson, M., Brown, R. D., Groisman, Ya, Pavel, Labba, N., Radionov, V., Barry, R. G., Bulygina, O. N., Essery, Richard L. H., Frolov, D. M., Golubev,Vladimir N., Grenfell, Thomas C., Petrushina, Marina N., Razuvaev, Vyacheslav N., Robinson,David A., Romanov, Peter, Shindell, Drew, Shmakin, Andrey B., Sokratov, Sergey A., Warren, Stephen and Yang, Daquing (2011) The 
Open access e-Journal

Earth Science India, eISSN: $0974-8350$

Vol. 10 (II), April, 2017, pp. 63- 81

http://www.earthscienceindia.info/

Changing Face of Arctic Snow Cover: A Synthesis of Observed and Projected Changes. AMBIO, v. 40, pp. 17-31.

Wulder, M. A., Nelson, T. A., Derksen, C. and Seemann, D. (2007) Snow cover variability across central Canada (1978-2002) derived from satellite passive microwave data. Clim. Chan., v. 82, pp. 113-130.

Yang, T., Hao, X., Shao, Q., Xu, C., Zhao, C., Chen, X. and Wang, W. (2012) Multi-model ensemble projections in temperature and precipitation extremes of theTibetan Plateau in the $21^{\text {st }}$ century. Global Planet. Change, v. 80-81, pp. 1-13.

Zarenistanak, M., Dhorde, A., G., Kripalani, R. H. and Dhorde, A. A. (2014b) Trends and projections of temperature, precipitation, and snow cover during snow cover-observed period over southwestern Iran. Theor. Appl. Climatol., DOI 10.1007/s00704-014-1287-8 b.

Zarenistanak, M., Dhorde, A. and Kripalani, R. H. (2014a) Temperature analysis over southwest Iran: trends and projections. Theor. Appl. Climatol., v. 116, pp. 103-117.

(Received: 02.10.2015; Accepted: 08.02.2017) 